\title{
EXPERIMENTAL STUDY ON CORROSION OF STEEL IN SOIL
}

\section{MEDIUM}

\author{
Ishaq T. Gezawa ${ }^{1}$, G.Gangha ${ }^{2}$, N.P Rajamane ${ }^{3}$, N.Ganapathy Ramasamy ${ }^{4}$ \\ ${ }^{1}$ Student M.tech, Construction Engineering and Management Civil Engineering Department, SRM University, Tamil \\ Nadu, India \\ ${ }^{2}$ Assistant Professor Civil Engineering Department SRM University, Tamil Nadu, India \\ ${ }^{3}$ Professor Head of center for Advance concrete research (CACR), SRM University, Tamil Nadu, India \\ ${ }^{4}$ Assistant Professor, Civil Engineering Department SRM University, Tamil Nadu, India
}

\begin{abstract}
There are many practical situation were steel is exposed to soil. Deterioration of steel in such case it depends upon the nature of soil, more especially the types and the concentration of ions present in the moisture within the soil, since soil vary in nature it is necessary to understand the nature of corrosion of steel in each of soil samples. This aspect was taken for the investigation and present in this paper. The weight and electrochemical methods of evaluating the corrosion rate were used in which four types of soil available around SRM university campus were utilized during the experimental work. Steel coupon of $12 \mathrm{~mm}$ diameter and $100 \mathrm{~mm}$ length was used, for each soil three artificial environments were created and electrochemical potential measuring was made for five weeks. The test shows that presence of chlorides ions in the soil create very severe environment and the drying of soil reduce the rate of corrosion.
\end{abstract}

Keywords, Corrosion of steel, Soil, Weight method, Electrochemical potential method

\section{INTRODUCTION}

Corrosion has been the subject for scientific study for more than 150 years.

It is the destructive attack of a metal by chemical or electrochemical reaction with its environment. Deterioration by physical causes is not called corrosion, but is described as erosion, galling, or wear. In some instances, chemical attack accompanies physical deterioration, as described by the following terms: corrosion - erosion, corrosive wear, or fretting corrosion. Nonmetals are not included in this definition of corrosion. Plastics may swell or crack, wood may split or decay, granite may erode, and Portland cement may leach away. "Rusting" applies to the corrosion of iron or iron - base alloys with formation of corrosion products consisting largely of hydrous ferric oxides. Nonferrous metals, therefore, corrode, but do not rust [9]

Corrosion can cause damage to everything from pipelines, bridge, and public building to vehicle, water and wastewater system and even home appliances. Losses sustained by industry and by governments amount to many billions of dollars annually, approximately \$276 billion in the United States, or $3.1 \%$ of the Gross Domestic Product (GDP), according to a recent study [5]. It has been estimated that about $25-30 \%$ of the total could be avoided if currently available corrosion technology were effectively applied[5]Studies of the cost of corrosion to Australia, Great Britain, Japan, and other countries have also been carried out. In each country studied, the cost of corrosion is approximately $3-4 \%$ of the Gross National Product [6]
In the world today, mild steel is used in different Engineering applications for the production of some automobile components, structural shapes (I, channel, angle etc.) and sheets which are used in pipelines, buildings, plants, bridges and tin cans. Mild steel pipelines and structures are usually expected to have a long working life. Similarly, Steel which is known for its high carbon content (about $0.2 \%$ to $2.1 \%$ ) has manganese $1.65 \%$, copper $0.6 \%$, silicon $0.6 \%$. It has outstanding ductility and toughness, high machinability and weldability which make its applications possible in the diverse engineering fields. With the increased utilization of this metal in the manufacturing and construction firms, one of the major problems encountered is the control of corrosion rate when exposed to different corrosive environments. Many constructions vital to the community are placed underground and thereby exposed to the corrosive action of soil. Water mains and sewers, steel pipelines for natural gas develop perforations, steel tanks for fuel oil and gasoline leak due to soil corrosion, lead sheathed telecommunications cables perforate by soil moisture, steel piling for the foundation of buildings, houses, and bridges in corrosive soils become susceptible to settling; the steel foundations and anchoring stays in power pylons, corrosion will damage pylon foundations and stays which will lead to a drastic disturbance in the supply of electricity to the country. Therefore studying the corrosivity nature of the soil is very important for the efficiency and safety of our infrastructures. The risk of corrosion needs to be estimated before the installation of underground structures. 
Iron and many other metals used in underground constructions been coated with a thin film of oxide immediately after being exposed to air. Such a film on iron may be merely a few molecular thickness but, nevertheless, furnishes some degree of protection against further oxidation or corrosion. At sufficiently high temperatures oxygen can diffuse through, around, and under these films so that the film is increasing in thickness, forming scale that may flake off to expose fresh surfaces for the continuing reaction. Most of the corrosion of iron (and other metals) in underground service at normal or moderate temperature is the result of an electrochemical reaction. Numerous problems related to soil impact in embedded steel structures are due to the unfavorable interaction between water and soil. Underground soil corrosion is primarily influenced by the following factors:

- $\quad$ Presence of soil moisture,

- Supply of oxygen,

- Redox potential,

- $\mathrm{pH}$ value,

- $\quad$ Soil resistivity, Microbial activity.

\subsection{Mechanism of Soil Corrosion:}

The corrosion process consists of four essential elements.

(a) An anode,

(b) A cathode,

(c) An electrolyte, and

(c) An electrical conductor connecting the cathode to anode.

An electrolyte can be any liquid, paste, or gas, which can conduct electricity by the migration of ions. In the case of underground corrosion, the electrolyte is the moist or water in the soil.

Corrosion is an electrochemical process that involves the passage of electrical currents on a micro or macro scale. The change from the metallic to the combined forms occurs by an "anodic" reaction:

\section{$\mathrm{M} \longrightarrow \mathrm{M}+\quad+\mathrm{e} \ldots 1.0$ \\ (Metal)(Soluble Salt) (Electron)}

This reaction produces free electrons, which pass within the metal to another site, on the metal surface (the cathode), where it is consumed by the cathodic reaction shown below:
In acidic soils, the cathodic reaction is:

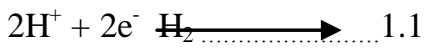

In neutral soils, the cathodic reaction involves the consumption of oxygen dissolved in the soil moisture.

$\mathrm{O}_{2}+2 \mathrm{H}_{2} \mathrm{O}+4 \mathrm{e}^{-} \stackrel{4 \mathrm{OH}^{-}}{\rightarrow} \ldots \ldots . . .1 .2$

(Alkali)

Corrosion thus occurs at the anode but not at the cathode (unless the metal of the cathode is attacked by alkali). The $\mathrm{OH}^{-}$ions react with $\mathrm{Fe}^{2+}$ ions to form ferrous hydroxide (corrosion products) according to equation:

$\mathrm{Fe}^{2+}+2 \mathrm{OH}^{-} \mathrm{Fe}(\mathrm{OH})_{2 \ldots} \rightarrow 1.3$

When the cathode and anode are closely situated and the $\mathrm{pH}$ value of the soil is greater than about 5, the corrosion product can form a coating which will provide some protection to the steel surface. Under certain conditions, however, the anode and cathode can be more widely separated and in extreme cases on a pipeline or a cable by as much as one or two kilometers. The metal ions formed at the anode will migrate with the current towards the cathode and the $\mathrm{OH}$ - ions formed at the cathode will migrate towards the anode. The corrosion products are then precipitated somewhere between the anode and Cathode. They therefore do not provide any protective coating to the anode. As a result pitting can occur at the anode, with the surfaces showing shiny metal. If the cathode area is much larger than that of the anode then the anodic current density will be high resulting in a high rate of pitting. Localized corrosion can lead to perforation and major damage; for example, oil tanks or pipes whereas single pits are of less importance for loadbearing structures such as steel piling.

In order to understand the nature of soil around the campus with the reference to its corrosion nature, sample of different location were drawn and used for embedding the steel specimen. The nature of corrosion was monitored by the loss of weight of the steel coupon and measuring the electrochemical potential of corrosion using $\mathrm{Cu} / \mathrm{CuSo}_{4}$. Accelerated corrosion rate of steel was introduced by adding sodium chloride solution to the soil. These tests data relates to observation for the period of 12 weeks for weight methods and five weeks for electrochemical potential method.

Table - 1: Detail of soil samples in grams

\begin{tabular}{|l|l|l|l|}
\hline Sample ID & Location of sample & $\begin{array}{l}\text { Nature of soil } \\
\text { classification as per } \\
\text { ASTM D 2487 - 06 }\end{array}$ & $\begin{array}{l}\text { Coefficient of } \\
\text { uniformity }\end{array}$ \\
\hline S1 & Sake soil & Gravels & $8.57>6$ \\
\hline S2 & East Potheri & Sand & $6.0>4$ \\
\hline S3 & Main building & $8.51>6$ \\
\hline S4 & Aerospace laboratory & sand & $8.95>6$ \\
\hline
\end{tabular}




\section{DETAIL OF EXPERIMENTAL WORK}

\subsection{Soil Media}

About $9 \mathrm{~kg}$ of each soil sample was collected from four location described in table 1

\subsection{Steel Coupon}

Steel coupon used was HSD bar of $12 \mathrm{~mm}$ and $100 \mathrm{~mm}$ length. Each test specimen was cleaned with brush before putting the coupon in the soil.

\subsection{Placing the Steel Coupon in the Soil Sample for}

\section{Corrosion Measurement by Weight Method.}

$4.5 \mathrm{~kg}$ of each of the sample was placed in the plastic tray $(220 \times 100 \times 140) \mathrm{mm}$. the depth of the soil in each was about $80 \mathrm{~mm}$ and the steel coupon was placed at the mid depth of the soil as shown in figure 1

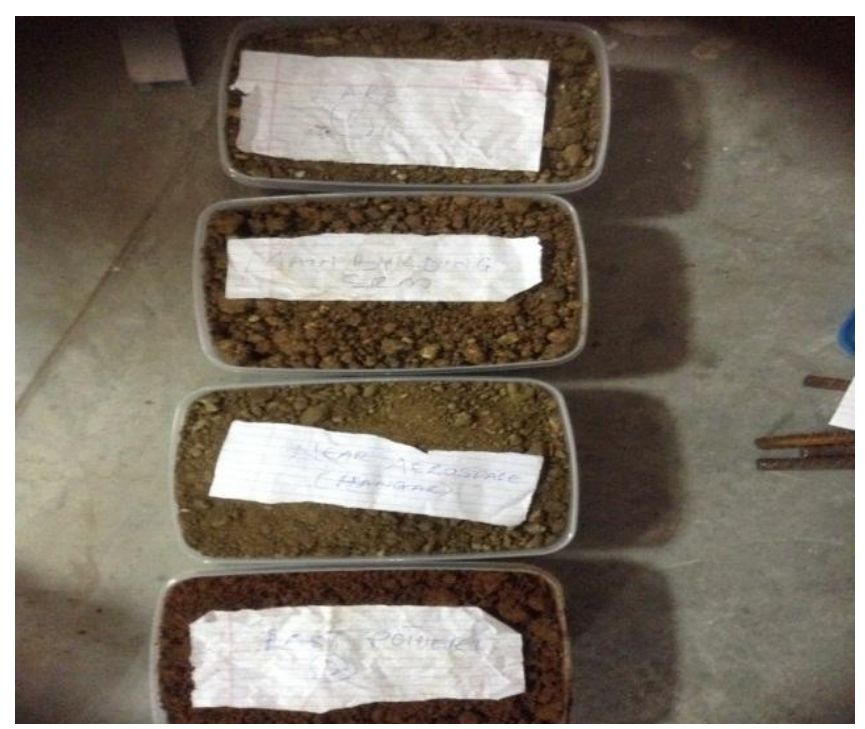

Fig - 1: Soil sample

\subsection{Placing the Steel Coupon in the Soil Sample for}

\section{Corrosion Measurement by Electrochemical}

\section{Potential Method.}

For each soil sample following exposure condition were generated

(i) Natural soil condition

(ii) Soil mix with water corresponding to optimum moisture content(OMC)

(iii) Soil mixed with $5 \%$ of sodium chloride solution (5\% solution was prepared by dissolving 5 grams of sodium chloride (salt) in 95 grams of water.

\subsection{Weight Measurement on Steel Coupon}

A digital balance of 200 grams capacity and having an accuracy of 0.1 milligrams. Initial weight of steel coupon was taken before placing the coupon in the soil media. After interval of two weeks the specimens were taken out from the tray and manually cleaned with wire brush to remove the corrosion product.

\subsection{Electrochemical Potential Measurement}

$\mathrm{Cu} / \mathrm{CuSO}_{4}$ reference electrodes was prepared using a plastic tube of diameter $20 \mathrm{~mm}$ and $1005 \mathrm{~mm}$ length and filled with saturated $\mathrm{Cu} / \mathrm{CuSO}_{4}$ solution copper rod of $3 \mathrm{~mm}$ diameter was used as an electrode, the end of the tube was sealed with wooden plug the wooden material being forests gives electrical conductivity between the reference electrode and the soil.The copper electrode is connected through conventional wire electrochemical potential reading was recorded on high impedance voltmeter as shown in figure 2

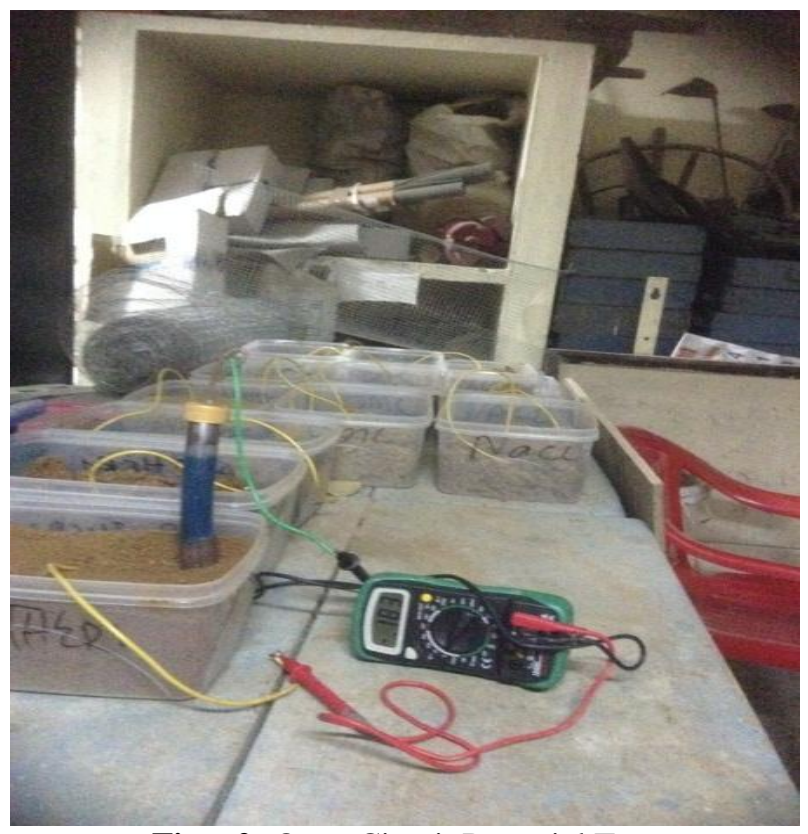

Fig - 2: Open Circuit Potential Test

\section{TEST RESULT AND DISCUSSION}

\subsection{Corrosion Rate through Weight Method}

For each exposure time t, weight loss of each test coupon was computed by the following equation

$$
C R=(k \times \Delta w) / A \times T \times \rho .
$$

Where:

$\mathrm{CR}=$ corrosion rate $\mathrm{mm} / \mathrm{yr}$.

$k=$ Constant for unit conversion $\left(8.76 \times 10^{4}\right)$

$\Delta w=$ weight loss in gm. (weight at the beginning of the test weight at the end of the test)

$\mathrm{A}=$ Exposed surface area of Coupon $\mathrm{cm}^{2}$

$T=$ Time of exposure in hours,

$\rho=$ Density of mild steel $\left(7.86 \mathrm{~g} / \mathrm{cm}^{3}\right)$ 
Table - 2a: Weight of steel coupon in grams

\begin{tabular}{|l|l|l|l|l|l|l|l|}
\hline \multicolumn{9}{|l|}{ Exposure time (Week) } \\
\hline Soil media & $(0)$ & $\begin{array}{l}(2) \\
(336 H R)\end{array}$ & $\begin{array}{l}(4) \\
(672 H R)\end{array}$ & $\begin{array}{l}(6) \\
(1008 H R)\end{array}$ & $\begin{array}{l}(8) \\
(1344 H R)\end{array}$ & $\begin{array}{l}(10) \\
(1680 H R)\end{array}$ & $\begin{array}{l}(12) \\
2016 H R\end{array}$ \\
\hline S1 & 88.9178 & 88.8178 & 88.5512 & 87.4845 & 85.9814 & 83.8803 & 81.2484 \\
\hline S2 & 88.9178 & 88.7178 & 88.3415 & 87.3914 & 85.7402 & 83.2287 & 80.2116 \\
\hline S3 & 88.9178 & 88.6177 & 88.3000 & 87.5412 & 86.1402 & 84.3061 & 81.6290 \\
\hline S4 & 88.9178 & 88.5627 & 88.4399 & 87.6098 & 86.0065 & 83.7711 & 80.8830 \\
\hline
\end{tabular}

Table - 2b: Weight loss of Coupons in grams

\begin{tabular}{|l|l|l|l|l|l|l|l|}
\hline \multicolumn{7}{|l|}{ Exposure time (Week) } \\
\hline Soil media & $(0)$ & $\begin{array}{l}(2) \\
(336 \mathrm{HR})\end{array}$ & $\begin{array}{l}(4) \\
(672 \mathrm{HR})\end{array}$ & $\begin{array}{l}(6) \\
(1008 \mathrm{HR})\end{array}$ & $\begin{array}{l}(8) \\
(1344 \mathrm{HR})\end{array}$ & $\begin{array}{l}(10) \\
(1680 \mathrm{HR})\end{array}$ & $\begin{array}{l}(12) \\
2016 \mathrm{HR}\end{array}$ \\
\hline S1 & 0.0000 & 0.1000 & 0.2666 & 1.0667 & 1.5031 & 2.1011 & 2.6321 \\
\hline S2 & 0.0000 & 0.2000 & 0.3763 & 0.9501 & 1.6512 & 2.5115 & 3.0171 \\
\hline S3 & 0.0000 & 0.3001 & 0.3172 & 0.7588 & 1.4010 & 1.8341 & 2.1771 \\
\hline S4 & 0.0000 & 0.3551 & 0.3779 & 0.8301 & 1.6033 & 2.2354 & 2.8881 \\
\hline
\end{tabular}

Table - 2c: Rate of Corrosion in $\mathrm{mm} / \mathrm{yr}$

\begin{tabular}{|l|l|l|l|l|l|l|}
\hline \multicolumn{6}{|l|}{ Exposure time (Week) } \\
\hline Soil media & $\begin{array}{l}\text { WEEK 0 to 2 } \\
(336 \mathrm{HR})\end{array}$ & $\begin{array}{l}\text { WEEK 2 to 4 } \\
(672 \mathrm{HR})\end{array}$ & $\begin{array}{l}\text { WEEK 4 to 6 } \\
(1008 \mathrm{HR})\end{array}$ & $\begin{array}{l}\text { WEEK6 to 8 } \\
(1344 \mathrm{HR})\end{array}$ & $\begin{array}{l}\text { WEEK 8 to 10 } \\
(1680 \mathrm{HR})\end{array}$ & $\begin{array}{l}\text { WEEK10 } \\
12(2016 \mathrm{HR})\end{array}$ \\
\hline S1 & 0.0830 & 0.1106 & 0.2951 & 0.3119 & 0.3488 & 0.3641 \\
\hline S2 & 0.1660 & 0.1562 & 0.2629 & 0.3426 & 0.4169 & 0.4174 \\
\hline S3 & 0.2491 & 0.1319 & 0.2099 & 0.2907 & 0.3044 & 0.3703 \\
\hline S4 & 0.2948 & 0.1568 & 0.2297 & 0.3327 & 0.3711 & 0.3999 \\
\hline
\end{tabular}

Table - 3: Corrosion rate result for the total duration

\begin{tabular}{|l|l|l|l|l|}
\hline Soil media & $\begin{array}{l}\text { INITIAL } \\
\text { WEIGHT(g) }\end{array}$ & $\begin{array}{l}\text { FINAL } \\
\text { WEIGHT(g) }\end{array}$ & $\begin{array}{l}\text { WEIGHT LOSS FOR } \\
\text { THREE MONTH } \\
(2016 \mathrm{HR})\end{array}$ & $\begin{array}{l}\text { CORROSION RATE } \\
\mathrm{mm} / \mathrm{yr}\end{array}$ \\
\hline S1 & 88.9178 & 81.2484 & 7.6694 & 1.060 \\
\hline S2 & 88.9178 & 80.2116 & 8.7064 & 1.204 \\
\hline S3 & 88.9178 & 81.6290 & 7.2888 & 1.0 \\
\hline S4 & 88.9178 & 80.8830 & 8.0348 & 1.111 \\
\hline
\end{tabular}

Charts for weight loss and corrosion rate for the experiment

\section{Weight loss}

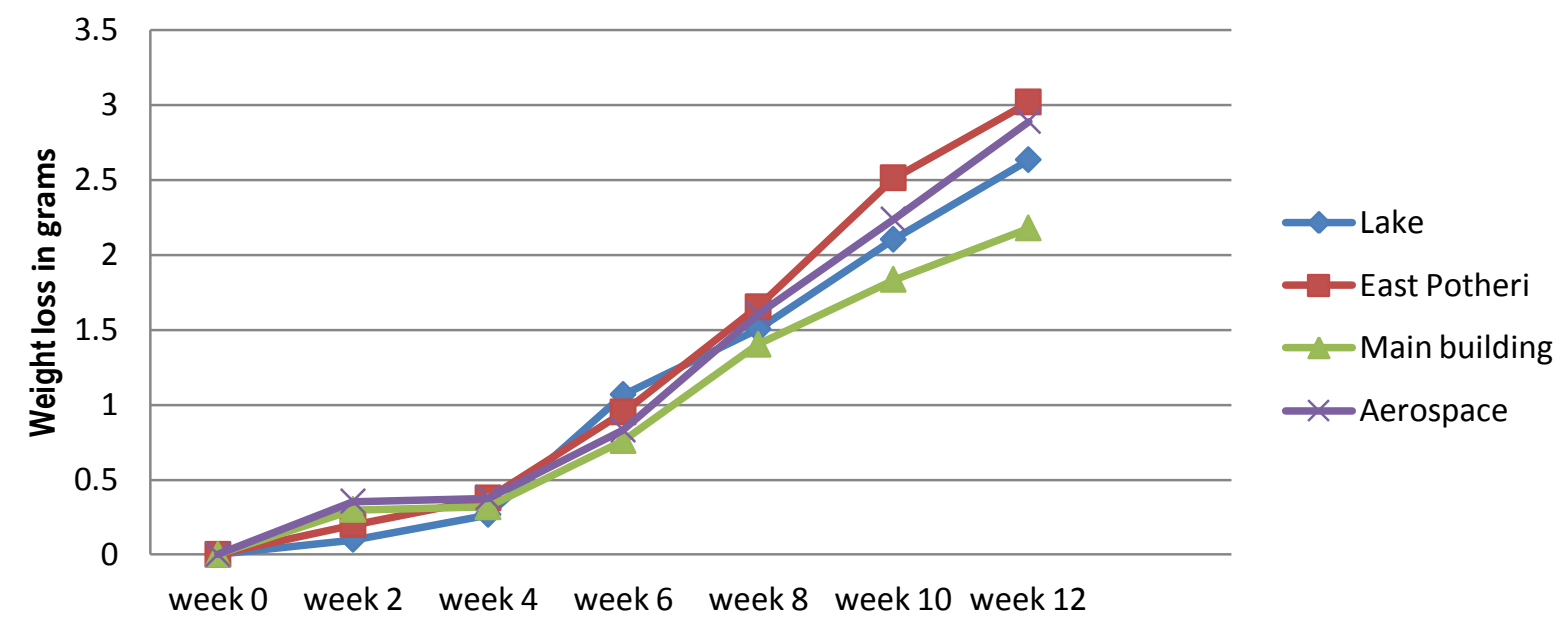

Chart - 1: graph of Weight loss against Time 


\section{Corrosion rate}

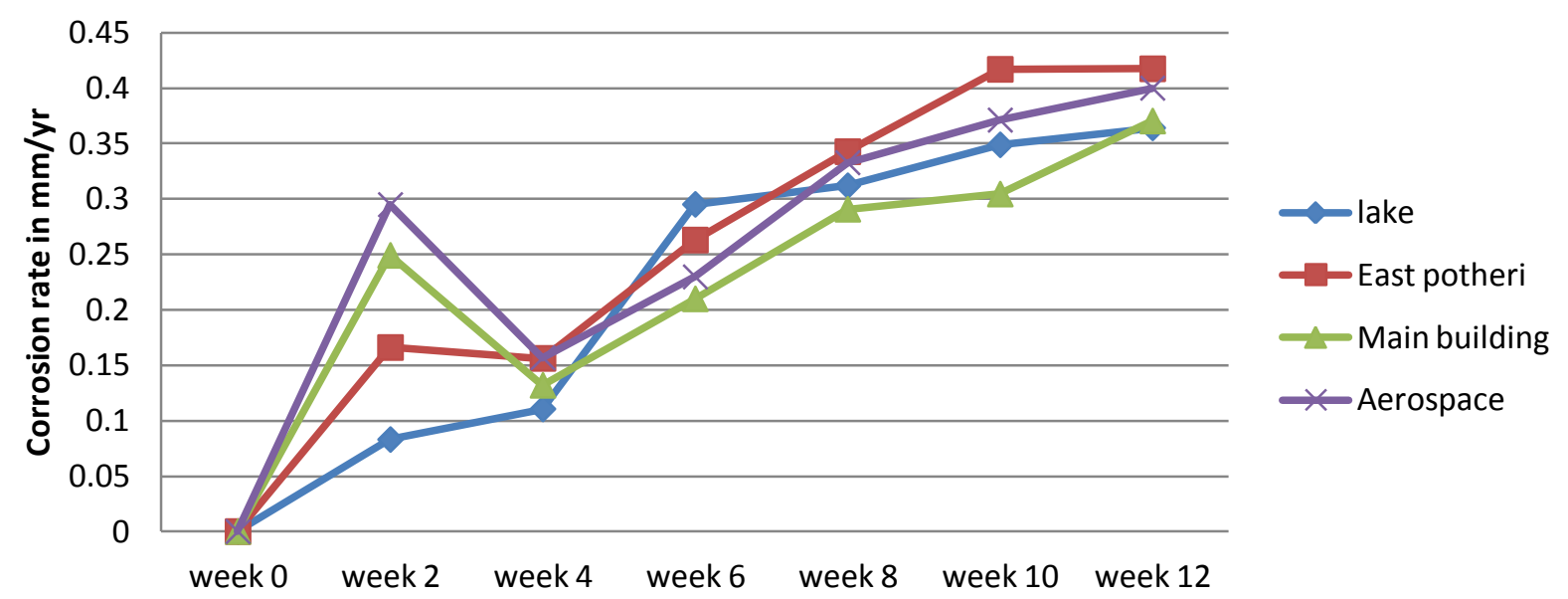

Chart - 2: graph of corrosion rate against Time

The test given in table 3 indicates that the corrosion rate in the soil is around $1 \mathrm{~mm} / \mathrm{yr}$. This rate is very high compared to corrosion rate given in published literature. In one of the references the corrosion rates in moving sea water (i.e. flowing water) is around $8 \mathrm{mil} / \mathrm{yr}$ corresponding to $0.2 \mathrm{~mm} / \mathrm{yr}$ by Table SP-B1 of ASME B31.8S. The reason for this is being explored; it looks that the methods of removal of corrosion product from the test specimen need to be modify suitably the use of cleaning procedure given in ASTM G1.

\subsection{Electrochemical Potential Measurement}

Electrochemical potential result for corrosion rate $(\mathrm{mV})$.using copper/copper sulphate half-cell electrode. The probability of the corrosion activity was given by ASTM C876 using a copper/copper sulphate half-cell ,For readings of $-350 \mathrm{mV}$ and greater there is a $95 \%$ chance of active steel corrosion, For readings -200 to $-350 \mathrm{mV}$ there is a $50 \%$ chance of active steel corrosion, For readings less than $200 \mathrm{mV}$ there is only $5 \%$ chance of active steel corrosion.

Table - 4: Electrochemical potential measurement in millivolt $(\mathrm{mV})$

\begin{tabular}{|c|c|c|c|c|c|}
\hline WEEKS & STATE & $\begin{array}{l}\text { POTHERI } \\
\text { SOIL }\end{array}$ & $\begin{array}{l}\text { AEROSPACE } \\
\text { SOIL }\end{array}$ & LAKE SOIL & $\begin{array}{l}\text { MAIN } \\
\text { BUILDING }\end{array}$ \\
\hline \multirow[t]{3}{*}{0 . } & NATURAL & -347 & -420 & -280 & -370 \\
\hline & OMC & -490 & -449 & -530 & -509 \\
\hline & Nacl & -568 & -525 & -539 & -551 \\
\hline \multirow[t]{3}{*}{1.} & NATURAL & -225 & -300 & -149 & -187 \\
\hline & OMC & -599 & -565 & -557 & -500 \\
\hline & Nacl & -610 & -589 & -560 & -619 \\
\hline \multirow[t]{3}{*}{2.} & NATURAL & -227 & -205 & -157 & -185 \\
\hline & OMC & -434 & -442 & -468 & -496 \\
\hline & Nacl & -524 & -590 & -560 & -600 \\
\hline \multirow[t]{3}{*}{3.} & NATURAL & -185 & -165 & -165 & -197 \\
\hline & OMC & -350 & -249 & -233 & -306 \\
\hline & Nacl & -468 & -540 & -509 & -513 \\
\hline \multirow[t]{3}{*}{4.} & NATURAL & -170 & -121 & -131 & -154 \\
\hline & OMC & -327 & -184 & -150 & -234 \\
\hline & Nacl & -414 & -491 & -483 & -472 \\
\hline \multirow[t]{3}{*}{5.} & NATURAL & -147 & -104 & -113 & -141 \\
\hline & OMC & -282 & -165 & -134 & -218 \\
\hline & Nacl & -380 & -466 & -429 & -412 \\
\hline
\end{tabular}


(1) The data given in table 4 indicate that soil in natural moisture condition is less compared to OMC and salt water.

(2) Soil mixed with sodium chloride solution recorded most negative electrochemical potential values indicating probability of higher corrosion rate

(3) For each exposure condition there seem to be nonsignificant different between electrochemical potential measured in the four types of soil taken, thus it looks the nature of corrosion of steel is almost similar in the entire soil sample taken because the classification of the three soils sample is the same.However, the actual exposure condition determines the rates of corrosion.

\section{CONCLUDING REMARKS}

(1)Weight change as the measure of corrosion rate requires carefully preparation of specimen before exposing them to corrosion media and proper cleaning procedure to remove the corrosion product forms so that the base metal is not removed during the cleaning process.

(2) Electrochemical potential measurement are suitable enough to record the degree of corrosivity of the soil media $\mathrm{Cu} / \mathrm{CuSO}_{4}$ reference electrode was found to be useful to evaluate the corrosion of steel in soil media

(3) The soil sample in the SRM campus seems to be similar with reference to corrosion of steel.

(4) Table 3 shows that the gravel soil has the higher corrosion rate.

\section{RECOMMENDATION}

The experimental procedure described in this paper can be used to evaluate the different soil sample for the corrosivity particularly related to steel.

However the procedure need to be refine to get practically usable test reading

\section{REFERENCES}

[1]. A.V Uglynitsa, N.V Gilyazidnova, A.A Zhikharev, A.A Kargin (2014),' 'study of reinforcementcorrosion on expended clay concrete" Housing and Building National Research Center HBRC Journal 1-4.

[2]. Ali Husain, Arjumand Shah Bano and Javed Iqbal Qazi (2013)' 'Corrosion of Mild Steel Simulating Long Term Soil Burial Field Conditions Differing in Nutritional and Biotic Components'. World Applied Sciences Journal 22 (7), pp. 985-990

[3]. Amir Samimi, Ali BagheriI (2013) 'investigation of Corrosion in Oil and Gas Pipelines in Southwestern Iran", World of Sciences Journal; Vol.[02] pp.114-127.

[4]. Engr Dr A.C Uzorh (2013), 'Corrosion Properties of Plain Carbon Steels" The International Journal of Engineering and Science (IJES) Volume 2 pp.18-24.

[5]. Gerhardus H.Koch, Michiel P. H. Brongers, Neil G. Thompson, Y. Paul Virmani, and J. H. Payer, Corrosion Costs and Preventive Strategies in the United States, Supplement to Materials Performance, July 2002, Report No. FHWA - RD - 01 - 156 , Federal Highway Administration, McLean, VA,2002
[6]. J. Kruger, Cost of metallic corrosion, inUhlig' s(2000 ) Corrosion Handbook , 2nd edition , R. W. Revie , editor, Wiley, New York , , pp. $3-10$

[7]. N. A. Rahman, M.C. Ismail (2013)"Corrosion Protection Coating for Buried Pipelines"': a Short Review International Journal of Material Science Innovations (IJMSI) 1 (4), 207-217.

[8]. R.B. Petersen, R.E. Melchers (2012) ''long-term corrosion of cast iron cement lined pipes" Centre for Infrastructure Performance and Reliability, The University of Newcastle, Australia Paper 23 pp. (1- 12).

[9]. R. Winston Revie and Herbert H. Uhlig(2008), Corrosion and Corrosion Control, fourth edition, pp 1

[10]. Saleh A. Al-Fozan and Anees U. malik (2005) . "'effect of seawater level on corrosion behavior of different alloys' Saline Water Desalination Research Institute Saline Water Conversion Corporation (SWCC) pp. 1 - 11

[11]. V. C. Cordoba, M. A. Meja, F. Echeverra, M. Morales, \& J. A. Calderon (2011) "'Corrosion mitigation of buried structures by soils modification" Ingeniare. Revista chilena de ingenie, vol. 19, pp. 486-497. 